\title{
Gelatinolytic activities (matrix metalloproteinase-2 and -9) and soluble extracellular domain of HER-2/neu in pleural effusions
}

\author{
ANGELINA DI CARLO ${ }^{1}$, ANGELA MARIANO ${ }^{2}$, DANIELA TERRACCIANO ${ }^{2}$, CLAUDIA MAZZARELLA $^{2}$, \\ SONIA GALZERANO ${ }^{3}$, MARCELLINO CICALESE $^{3}$, CIRIACO CECERE $^{3}$ and VINCENZO MACCHIA ${ }^{2}$ \\ ${ }^{1}$ Dipartimento di Medicina Sperimentale, Università di Roma 'La Sapienza', Viale Regina Elena 324, \\ I-00161 Roma; ${ }^{2}$ Dipartimento di Biologia e Patologia Cellulare e Molecolare 'L. Califano', ${ }^{3}$ Cattedra \\ di Chirurgia Toracica, Università di Napoli 'Federico II', Via S. Pansini 5, I-80131 Napoli, Italy
}

Received January 12, 2007; Accepted February 20, 2007

\begin{abstract}
Matrix metalloproteinases (MMPs) are proteolytic enzymes that are implicated in multiple stages of cancer progression including invasion and metastasis. MMPs exert these effects by cleaving a diverse group of substrates, which include not only structural components of the extracellular matrix, but also growth factor receptors. By gelatin zymography we verified MMP activity in the pleural effusions of patients with benign and malignant disease. Of these patients, 32 had malignant pleural effusion, consisting of 20 breast cancer, 6 non-small cell lung carcinoma, 4 ovarian carcinoma, and 2 colonic adenocarcinoma, and 10 had benign pleural effusion (5 pleurisy and 5 cirrhosis). Zymography showed the constant presence of a substantial amount of MMP-2 in all samples analyzed, whereas MMP-9 was present to lesser quantities. MMP-2 activity was enhanced in pleural effusions from patients with benign diseases compared with cancer patients. MMP-9 was present in 59\% of cancer patients and the lytic activity was enhanced in pleurisy and absent in cirrhosis. Furthermore, we determined the pleural effusion levels of the soluble extracellular domain of HER-2/neu. The levels of HER-2/neu ECD were above the cut-off value in breast cancer patients. No correlation between gelatinolytic activities and high HER-2/neu ECD values was found.
\end{abstract}

\section{Introduction}

Pleural effusion represents a common and challenging diagnostic problem in the practice of pulmonary medicine with

Correspondence to: Professor Vincenzo Macchia, Dipartimento di Biologia e Patologia Cellulare e Molecolare 'L. Califano', Università degli Studi di Napoli 'Federico II', Via S. Pansini 5, I-80131 Napoli, Italy

E-mail:macchia@unina.it

Key words: matrix metalloproteinase-2, matrix metalloproteinase-9, soluble extracellular domain of HER-2/neu, pleural effusions, cancer diverse and non-similar etiologies. One of the main causes of pleural effusions is malignancy. In fact, several types of carcinoma develop a pleural effusion in the course of the disease. Metastasis from breast or ovarian carcinoma are the most frequent etiology for the presence of malignant pleural effusions in female patients, whereas lung carcinoma and malignant mesothelioma account for a relatively large number of cases in both sexes (1). Involvement of the pleural cavity by carcinoma may occur at any point of the clinical course and may be the first symptom of metastatic disease (2). Usually diagnosis is carried out by cytological examination of pleural fluid. This is a simple and reliable method for the diagnosis of malignant effusions, but its sensitivity is only 40-60\% (3), even lower in clinical practice. Cytological examinations are based on the cellular morphology, which may raise difficulties in distinguishing carcinoma cells from reactive mesothelial cells. Sometimes, carcinoma cells without typical morphological changes or enough number could not be diagnosed cytologically (4). Closed pleural biopsy confers a small additive diagnostic value. Thoracoscopy is the preferred diagnostic procedure in patients with cytology-negative pleural effusion who are suspected of having pleural malignancy $(5,6)$. This method has a great sensitivity but, in addition to being expensive, it imposes physical and mental stress to the patient. The determination of tumor markers in pleural effusions has been proposed as an alternative, non-invasive way of establishing a diagnosis of pleural malignancy and a number of tumor markers has been intensively evaluated (7-11). However, their precise sensitivities in identifying malignant pleural effusion remains controversial.

It is generally believed that the oncogene family of the growth factor receptor (HER family) play an important role in the development of human cancer (12). An important member of this family, the human epidermal growth factor receptor-2 (HER-2), which is also referred to as HER-2/neu or c-erbB-2, is structurally and functionally related to the $\mathrm{v}$-erbB retroviral oncogene and has intrinsic tyrosine kinase activities (13). Recent evidence, however, indicates that certain matrix metalloproteinases (MMPs) are implicated in multiple stages of cancer progression including invasion and metastasis (14-16). Indeed some of the c-oncogenes may contribute to tumorigenesis by regulating the expression of MMPs. For 
example, transfection of MCF-10A breast cancer cells with either $c$-erbB-2 or c-ras resulted in increased expression of MMP-2 (17), whereas transfection of MCF-7 cells with the ets gene led to increased production of MMP-9 (18). Furthermore, it is known that the heavily glycosylated extracellular domain (ECD, p105) of the HER-2 is shed in plasma and serum from healthy individuals and patients with cancer $(19,20)$. The cleavage of the HER-2/neu ECD involves MMP activity and this process is inhibited by the MMP inhibitor TIMP-1 but not by TIMP-2 (21).

In the present preliminary study, we measured the MMP-2 and MMP-9 (also known as gelatinase A and gelatinase B) activity levels in the pleural effusions using gelatin zymography. These levels were compared with the pleural fluid content of soluble extracellular domain of HER-2/neu with the following objectives: i) to support the diagnostic and prognostic value of pleural fluid gelatinolytic activities; and ii) to determine the possible association between pleural effusion forms of MMP-2 and -9 with the levels of HER-2/neu.

\section{Materials and methods}

Pleural effusion samples. Pleural effusions were collected from patients admitted, between September 2004 and September 2005, for diagnosis, to the Surgery Department of the Faculty of Medicine of the University 'Federico II' of Naples. Patient evaluation included anamnesis, physical examination, chest$\mathrm{X}$-ray thoracentesis with biochemical cytologic and bacteriology study of pleural fluid. When the result of the cytologic examination was negative or in doubt patients underwent blind pleural biopsies and/or thoracoscopic guided biopsies. All pleural effusions had definite etiologies. Informed consent was obtained according to institutional guidelines. Patients' age ranged from 32 to 78 years at diagnosis. Fresh pleural fluid was obtained by thoracentesis, collected in plastic sterile tubes without coagulation accelerators to prevent the release of gelatinases during platelet activation and rapidly brought to our laboratory. Tubes were centrifuged at $1600 \mathrm{x} g$ for $10 \mathrm{~min}$. supernatants were aliquoted and stored at $-80^{\circ} \mathrm{C}$ until use. For each sample, determination of protein concentration was performed using the method of Bradford (22). Each aliquot was used only once in order to prevent enzyme activation due to freeze-thawing processes.

Materials. Gelatinase A (from human fibrosarcoma cells) and gelatinase B (isolated from human blood) were purchased from Hoffmann-La Roche, Ltd. (Basel, Switzerland). Triton X-100, calcium chloride $\left(\mathrm{CaCl}_{2}\right)$, glycerol, gelatin, ethylenediaminetetraacetic (EDTA), and phenylmethylsulphonyl fluoride (PMSF) were from Sigma Chemical Co. (St. Louis, MO, USA). The protein assay reagent was from Bio-Rad Laboratories. All other reagents were available from commercial sources.

Gelatin zymography. MMP activity in each sample was determined through zymographic analysis under denaturating but non-reducing conditions as previously described (15). Briefly, $15 \mu \mathrm{g}$ of the total protein of each sample were mixed with sample buffer and applied directly without prior heating or reduction to $7.5 \%(\mathrm{w} / \mathrm{v})$ acrylamide gels containing $0.1 \%(\mathrm{w} / \mathrm{v})$ of gelatin. After removal of SDS from the gel by incubation in $2.5 \%(\mathrm{v} / \mathrm{v})$ Triton $\mathrm{X}-100$ for $1 \mathrm{~h}$, the gels were incubated at $37^{\circ} \mathrm{C}$ for $18 \mathrm{~h}$ in $50 \mathrm{mM}$ Tris- $\mathrm{HCl} \mathrm{pH} 7.6$ containing $0.2 \mathrm{M}$ $\mathrm{NaCl}, 5 \mathrm{mM} \mathrm{CaCl}_{2}$, and $0.02 \%$ (w/v) Brij 35. Gels were stained for $1 \mathrm{~h}$ in $30 \%$ methanol, $10 \%$ glacial acetic acid containing $0.5 \%(\mathrm{w} / \mathrm{v})$ Coomassie Brilliant Blue G 250 and destained in the same solution without dye for several hours. The gelatinolytic activity of each collagenase was evident as a clear band against the blue background of stained gelatin. The molecular sizes of bands displaying enzymatic activity were identified by comparison with prestained standard protein, as well as with purified gelatinase A or gelatinase B. To normalize the possible difference between zymograms an internal effusion sample from a patient was incorporated in every gel.

Control gels for MMPs. Control gels contained either of the MMP selective inhibitors, $20 \mathrm{mM}$ EDTA or $10 \mathrm{mM} 1,10$ phenanthroline, in the MMP incubation buffer to confirm that lysis bands were the results of MMPs. Furthermore, the character of proteolytic bands was analyzed by incubating the identical zymograms in $0.1 \mathrm{mg} / \mathrm{ml}$ of PMSF, a serine protease inhibitor; or $2 \mathrm{mM}$ Pefabloc, an irreversible serine protease inhibitor.

Analysis of the gels. Following zymography, the degree of gelatin digestion was quantified as previously described (23). Briefly, we used image analysis software (ImageQuant TL; Amersham Bioscience, Chicago, IL, USA) according to the manufacturer's specifications. The image of the gel was inverted to reveal dark bands on a white background. The molecular weight, volume and background of each band were determined. The relative amounts of the different forms of the proteinases were expressed as the integrated density $\mathrm{x}$ $10^{-3}$ (volume) of all the pixels above the background of each band per microgram of protein and as percentage of the total gelatinolytic activity.

Measurement of HER-2/neu. The soluble extracellular domain of epidermal growth factor-2 (HER-2/neu) was detected with the automated ADVIA Centaur analyzer (Bayer Diagnostic SpA, Milan, Italy), according to the manufacturer's specifications. This immunoassay utilized two monoclonal antibodies (TA-1 and NB3) which are specific for two different epitopes of the extracellular domain of the HER-2/neu oncoprotein (glycoprotein p105 with a molecular weight of 97-115 kDa).

\section{Results}

During a 1-year period, a total of 42 patients with pleural effusion were evaluated. Standard criteria were used to establish the etiology and the nature (malignant or benign) of pleural effusions (24). Of these patients 32 (6 males and 26 females) had a malignant pleural effusion: 20 breast cancer, 6 nonsmall lung cancer, 4 ovary cancer, 2 colon adenocarcinoma. Ten patients had benign pleural effusion: 5 pleurisy and 5 cirrhosis.

To investigate gelatinolytic activity present in pleural effusions, substrate gel zymography was performed. This method allows the detection of the metalloproteinases that exhibit significant gelatinolytic activity. Representative 


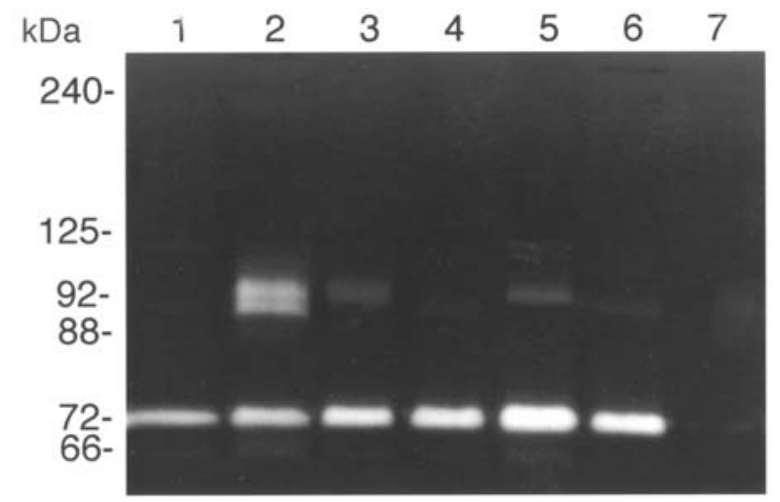

Figure 1. Gelatin zymography of pleural effusion specimens. Molecular weight standards are shown on the left. In all effusion samples, $15 \mu \mathrm{g}$ of protein was loaded onto the gel. Lanes 1-6, lung cancer (patients AA, PG, AP, CG, DF, DS); lane 7, lung cancer in presence of 1.1 phenathroline $10 \mathrm{mM}$ (patient PG).

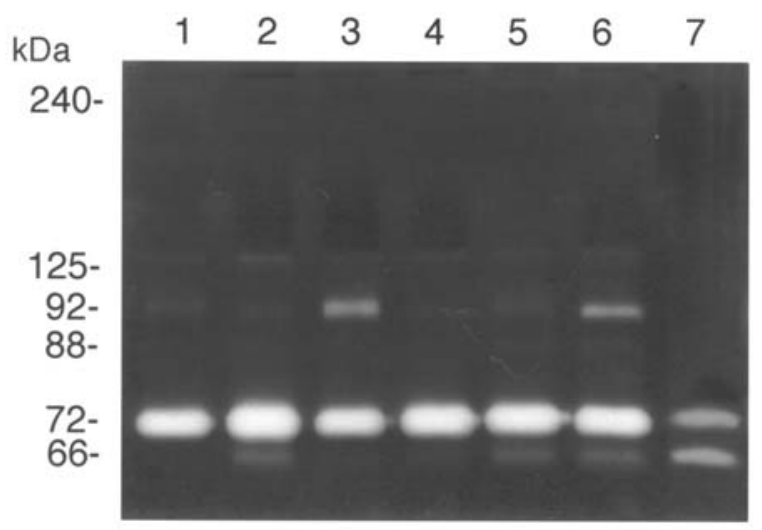

Figure 2. Gelatin zymography of purified gelatinase A and pleural effusion specimens. Molecular weight standards are shown on the left. In all effusion samples, $15 \mu \mathrm{g}$ of protein was loaded onto the gel. Lanes 1-6, breast cancer (patients NC, NG, CC, DG, DA, PP); lane 7, gelatinase A (MMP-2) $120 \mathrm{mU}$.

zymography results are shown in the figures. Polyacrylamide gels were evaluated for the presence of a clear zone representing degradation of gelatin by proteolysis. The nature of the lytic bands was confirmed by inhibition assays with selective inhibitors of MMPs (Fig. 1, lane 7) and with selective inhibitor of serine protease (data not shown). As shown in the figures zymographic analysis revealed the existence of a strong sharp band of gelatinolytic activity migrating at $\sim 72 \mathrm{kDa}$, a lytic band migrating at $\sim 92 \mathrm{kDa}$ and faint lytic bands with apparent molecular weight of 125, 88 and $66 \mathrm{kDa}$. Comparison of these gelatinolytic bands with prestained standard protein and purified gelatinase A (MMP-2) and gelatinase B (MMP-9) clearly identified the MMP-costituting bands as gelatinase A (proMMP-2, $72 \mathrm{kDa}$; and activated MMP-2, $66 \mathrm{kDa}$ ) (Fig. 2, lane 7) and gelatinase B (proMMP-9, $92 \mathrm{kDa}$; and activated MMP-9, $88 \mathrm{kDa}$ ) (Fig. 3, lane 1). The clear zones with a molecular weight higher than $92 \mathrm{kDa}$ might represent complexes of MMPs that are not dissociated in zymography. In fact, MMP-9 can be associated with a $25-\mathrm{kD}$ a protein with a band at $125 \mathrm{kDa}(23,25,26)$ that can form dimer or multidimer with lytic bands at $\sim 215$ and $240 \mathrm{kDa}$ (27). Following gelatin zymography, proteolytic bands were subjected to densitometric

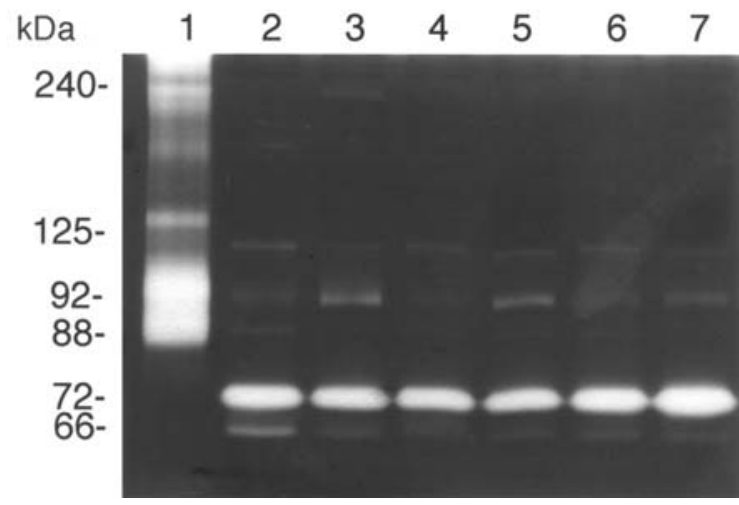

Figure 3. Gelatin zymography of gelatinase B and pleural effusion specimens. Molecular weight standards are shown on the left. In all effusion samples, $15 \mu \mathrm{g}$ of protein was loaded onto the gel. Lane 1, gelatinase B (MMP-9) $20 \mu \mathrm{U}$; lanes 2-7, breast cancer (patients IR, CA, DL, OF, PI, $\mathrm{RM})$.

analysis and the data expressed as the integrated density of all the pixels of each band (volume $\mathrm{x} 10^{-3} / \mu \mathrm{g}$ proteins), and as the percentage of the total gelatinolytic activity. A summary of expression patterns of proteinases in both benign and malignant pleural effusion specimens is shown in the tables. In the benign pleural effusions the total gelatinolytic activity ranged from 37 to 227 volume $\times 10^{-3} / \mu \mathrm{g}$ protein with a mean value \pm SE of $119 \pm 19$; whereas in malignant pleural effusions it ranged from $18.8-78.1$ volume $\times 10^{-3} / \mu$ g protein (mean, $43 \pm 1.8$ volume $\times 10^{-3} / \mu \mathrm{g}$ protein). MMP-2 was detected in all specimens analyzed. In the benign pleural effusions the lytic activity (range, 37-227; mean, 96.8 \pm 19 volume x 10-3/ $\mu \mathrm{g}$ protein) was 2.5 -fold higher than that observed in malignant effusion specimens (range, 15.3-77; mean, 38.1 \pm 1.9 volume x $10^{-3} / \mu \mathrm{g}$ protein). MMP-9 was detected in pleurisy and in $19 / 32(59 \%)$ of the malignant effusion specimens with a mean value $\pm \mathrm{SE}$ of $4.8 \pm 0.8$ volume $\times 10^{-3} / \mu \mathrm{g}$ protein (range, 1-17.5); however the lytic activity of gelatinase B was $\sim 8$-fold higher in pleurisy than in malignancy. Finally, in the patients with cirrhosis zymographic analysis revealed the existence of only the $72-\mathrm{kDa}$ band. As it concerns pleurisy, 4 out of 5 samples (80\%) showed lytic activity at $66 \mathrm{kDa}$ (active proMMP-2), presumably due to an autoactivation during the renaturation period. All pleurisy specimens had MMP-9 ranging in density between 6.8 and 77.7 volume $\times 10^{-3} / \mu \mathrm{g}$ protein with a mean value of $37.7 \pm 14$. Of these, 2 samples $(40 \%)$ showed a faint lytic band with a molecular weight at $\sim 88 \mathrm{kDa}$ (Table I). Moreover, one pleurisy specimen (patient MV) showed a small lytic activity at $240 \mathrm{kDa}\left(2.3\right.$ volume $\mathrm{x} 10^{-3} / \mu \mathrm{g}$ protein, 2.5\%) (Fig. 4, lane 4). As shown in Table II, in patients with breast carcinomas the density of the $72-\mathrm{kDa}$ lytic band ranged from 18.5 to 77 volume $\times 10^{-3} / \mu \mathrm{g}$ protein (mean, $41.3 \pm 2.9$ ), and the faint lytic band with lower molecular weight (66 kDa) was detected in 15/20 (75\%) of samples. The 92-kDa lytic band (pro MMP-9, gelatinase B) was detected in 14/20 (70\%) samples with a value ranging from 1 to 13.3 volume $\mathrm{x} 10^{-3} / \mu \mathrm{g}$ protein (mean, $4 \pm 0.7$ volume $\times 10^{-3} / \mu$ g protein). Moreover, 4 out of $14(28 \%)$ of these specimens showed a faint lytic band of $88 \mathrm{kDa}$ (active MMP-9), and 8 (57\%) showed a band at $125 \mathrm{kDa}$. As it concerns the non-small cell lung carcinomas, the density of the 72-kDa lytic band ranged from 15.3 to 69.5 
Table I. Pleural effusion MMP content (volume x 10-3/ $\mu$ g protein and percentage) related to HER-2/neu in benign disease.

\begin{tabular}{|c|c|c|c|c|c|c|c|c|c|c|c|c|c|}
\hline \multirow[b]{2}{*}{ Patient } & \multirow[b]{2}{*}{ Sex } & \multirow{2}{*}{$\begin{array}{c}\text { Age } \\
\text { (years) }\end{array}$} & \multirow[b]{2}{*}{ Disease } & \multirow{2}{*}{$\begin{array}{c}\text { Total MMPs } \\
\left.\text { (vol x } 10^{-3} / \mu \mathrm{g} \mathrm{pr}\right)\end{array}$} & \multicolumn{2}{|c|}{ MMP $92 \mathrm{kDa}$} & \multicolumn{2}{|c|}{ MMP 88 kDa } & \multicolumn{2}{|c|}{ MMP 72 kDa } & \multicolumn{2}{|c|}{ MMP 66 kDa } & \multirow{2}{*}{$\begin{array}{l}\text { HER-2/neu } \\
\text { (ng/ml) }\end{array}$} \\
\hline & & & & & A & B & A & B & A & $\mathrm{B}$ & A & B & \\
\hline MM & $\mathrm{F}$ & 67 & Pleurisy & 113.0 & 40.2 & 35.5 & 1.5 & 1.3 & 67.7 & 61.6 & 2.2 & 1.9 & 5.4 \\
\hline ML & M & 75 & Pleurisy & 75.2 & 6.8 & 9.0 & 0 & 0 & 68.4 & 91.0 & 0 & 0 & 9.5 \\
\hline $\mathrm{BN}$ & M & 72 & Pleurisy & 118.0 & 48.5 & 41.1 & 15.3 & 12.9 & 39.0 & 33.0 & 15.8 & 13.3 & 3.9 \\
\hline MV & M & 43 & Pleurisy & 92.0 & 15.3 & 16.6 & 0 & 0 & 71.0 & 77.0 & 3.3 & 3.6 & 4.9 \\
\hline $\mathrm{OA}$ & M & 42 & Pleurisy & 161.0 & 77.7 & 48.2 & 0 & 0 & 82.6 & 51.0 & 1.3 & 0.8 & 5.1 \\
\hline DV & $\mathrm{F}$ & 67 & Cirrhosis & 85.5 & 0 & 0 & 0 & 0 & 85.5 & 100.0 & 0 & 0 & 4.5 \\
\hline IG & M & 68 & Cirrhosis & 227.0 & 0 & 0 & 0 & 0 & 227.0 & 100.0 & 0 & 0 & 0.3 \\
\hline FD & M & 63 & Cirrhosis & 37.0 & 0 & 0 & 0 & 0 & 37.0 & 100.0 & 0 & 0 & 4.3 \\
\hline FI & $\mathrm{F}$ & 69 & Cirrhosis & 93.0 & 0 & 0 & 0 & 0 & 93.0 & 100.0 & 0 & 0 & 4.0 \\
\hline CA & $\mathrm{F}$ & 63 & Cirrhosis & 195.0 & 0 & 0 & 0 & 0 & 195.0 & 100.0 & 0 & 0 & 0.5 \\
\hline
\end{tabular}

$\mathrm{A}$, volume $\times 10^{-3} / \mu \mathrm{g}$ protein; $\mathrm{B}$, percentage. pr, protein.

Table II. Pleural effusion MMP content (volume x $10^{-3} / \mu \mathrm{g}$ protein and percentage) related to HER-2/neu in breast cancer.

\begin{tabular}{|c|c|c|c|c|c|c|c|c|c|c|c|c|c|c|}
\hline \multirow[b]{2}{*}{ Patient } & \multirow[b]{2}{*}{ Sex } & \multirow{2}{*}{$\begin{array}{c}\text { Age } \\
\text { (years) }\end{array}$} & \multirow{2}{*}{$\begin{array}{c}\text { Total MMPs } \\
\left.\text { (vol x } 10^{-3} / \mu \mathrm{g} \mathrm{pr}\right)\end{array}$} & \multicolumn{2}{|c|}{ MMP $125 \mathrm{kDa}$} & \multicolumn{2}{|c|}{ MMP $92 \mathrm{kDa}$} & \multicolumn{2}{|c|}{ MMP 88 kDa } & \multicolumn{2}{|c|}{ MMP $72 \mathrm{kDa}$} & \multicolumn{2}{|c|}{ MMP 66 kDa } & \multirow{2}{*}{$\begin{array}{l}\text { HER-2/neu } \\
\text { (ng/ml) }\end{array}$} \\
\hline & & & & A & B & A & B & A & B & A & B & A & B & \\
\hline $\mathrm{NC}$ & $\mathrm{F}$ & 44 & 36.1 & 0 & 0 & 1.9 & 5.3 & 0 & 0 & 34.0 & 94.0 & 0 & 0 & 21 \\
\hline NG & $\mathrm{F}$ & 71 & 44.6 & 0 & 0 & 1.0 & 2.2 & 0 & 0 & 42.1 & 94.4 & 1.5 & 3.4 & 10 \\
\hline $\mathrm{CC}$ & $\mathrm{F}$ & 63 & 39.7 & 0 & 0 & 7.6 & 19.0 & 0 & 0 & 32.0 & 81.0 & 0 & 0 & 93 \\
\hline DG & $\mathrm{F}$ & 72 & 48.6 & 0 & 0 & 0 & 0 & 0 & 0 & 48.6 & 100.0 & 0 & 0 & 46 \\
\hline DA & $\mathrm{F}$ & 62 & 63.6 & 0 & 0 & 0 & 0 & 0 & 0 & 60.1 & 94.5 & 3.5 & 5.5 & 11 \\
\hline PP & $\mathrm{F}$ & 39 & 50.4 & 0 & 0 & 7.0 & 13.8 & 0 & 0 & 40.8 & 81.0 & 2.6 & 5.1 & 73 \\
\hline DM & $\mathrm{F}$ & 58 & 78.1 & 0 & 0 & 0 & 0 & 0 & 0 & 77.0 & 98.5 & 1.1 & 1.5 & 15 \\
\hline DR & $\mathrm{F}$ & 59 & 67.4 & 3.5 & 5.2 & 2.8 & 4.1 & 1.4 & 2.1 & 56.3 & 83.5 & 3.4 & 5.0 & 45 \\
\hline ML & $\mathrm{F}$ & 64 & 26.2 & 1.2 & 4.6 & 2.6 & 9.9 & 0.6 & 2.3 & 20.8 & 79.4 & 1.1 & 4.2 & 59 \\
\hline GA & $\mathrm{F}$ & 62 & 31.4 & 0 & 0 & 0 & 0 & 0 & 0 & 31.4 & 100.0 & 0 & 0 & 29 \\
\hline $\mathrm{RM}$ & $\mathrm{F}$ & 41 & 25.0 & 0 & 0 & 0 & 0 & 0 & 0 & 18.5 & 74.0 & 6.5 & 26.0 & 25 \\
\hline PR & $\mathrm{F}$ & 58 & 29.0 & 0 & 0 & 1.1 & 3.8 & 0 & 0 & 27.2 & 94.0 & 1.0 & 3.4 & 41 \\
\hline EM & $\mathrm{F}$ & 47 & 21.4 & 0 & 0 & 0 & 0 & 0 & 0 & 21.4 & 100.0 & 0 & 0 & 60 \\
\hline IR & $\mathrm{F}$ & 34 & 45.3 & 1.3 & 2.8 & 1.6 & 3.5 & 0.5 & 1.1 & 40.2 & 88.7 & 1.5 & 3.3 & 42 \\
\hline $\mathrm{CA}$ & $\mathrm{F}$ & 44 & 59.4 & 0 & 0 & 6.7 & 11.3 & 0 & 0 & 52.0 & 87.0 & 0.7 & 1.2 & 38 \\
\hline DL & $\mathrm{F}$ & 53 & 53.5 & 1.4 & 2.6 & 1.7 & 3.2 & 0 & 0 & 49.5 & 92.5 & 2.3 & 4.3 & 20 \\
\hline $\mathrm{OF}$ & $\mathrm{F}$ & 32 & 49.3 & 0.4 & 0.8 & 4.9 & 9.9 & 0 & 0 & 42.5 & 86.0 & 1.5 & 3.0 & 27 \\
\hline PI & $\mathrm{F}$ & 60 & 77.1 & 0.75 & 1 & 2.2 & 2.8 & 0 & 0 & 73.0 & 94.0 & 1.0 & 1.3 & 12 \\
\hline $\mathrm{RM}$ & $\mathrm{F}$ & 66 & 38.8 & 0.44 & 1.1 & 1.6 & 4.1 & 0 & 0 & 36.0 & 93.0 & 0.83 & 2.1 & 29 \\
\hline VM & $\mathrm{F}$ & 54 & 51.7 & 4.5 & 8.7 & 13.3 & 25.7 & 2.9 & 5.6 & 22.8 & 44.0 & 8.2 & 15.8 & 17 \\
\hline
\end{tabular}

A, volume $\times 10^{-3} / \mu \mathrm{g}$ protein; B, percentage. pr, protein.

volume $\times 10^{-3} / \mu \mathrm{g}$ protein and the $66-\mathrm{kDa}$ lytic activity was observed only in one sample; whereas the 92-kDa lytic band was detected in 3 (50\%) samples (Table III) (Fig. 1, lanes 1-6). Three out of four ovary carcinomas showed only a strong lytic activity at $72 \mathrm{kDa}$ (Fig. 5, lanes 2-4), and one sample (patient
GM) showed lytic bands at 240, 125 and $92 \mathrm{kDa}$ as well as at 72 and $66 \mathrm{kDa}$ (Fig. 5, lane 1). In colon cancer, one specimen showed only the 72-kDa lytic band (Fig. 5, lane 5) and the other sample had also a faint lytic band corresponding to MMP-9 (Table III). 


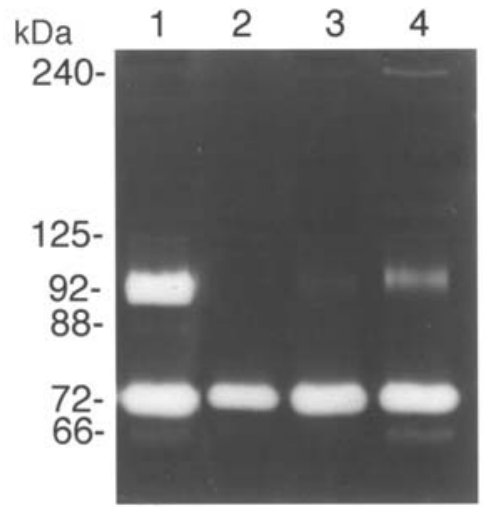

Figure 4. Gelatin zymography of pleural effusion specimens. Molecular weight standards are shown on the left. In all effusion samples, $15 \mu \mathrm{g}$ of protein was loaded onto the gel. Lane 1, pleurisy (patient OA); lanes 2 and 3, cirrhosis (patients CA, IG); lane 4, pleurisy (patient MV).

Soluble extracellular domain of epidermal growth factor-2 (HER-2/neu) was measured on the pleural effusions of all subjects studied (Tables I-III). Since normal pleural fluids were not available for HER-2/neu we established the cut-off value by the mean \pm 2 SD of the value obtained in the sera of 103 healthy subjects of the same age and the cut-off value of $15 \mathrm{ng} / \mathrm{ml}$ was considered. The samples with HER-2/neu value higher than the cut-off were considered positive. In the benign effusion specimens, the mean value $\pm \mathrm{SE}(4.2 \pm 0.9 \mathrm{ng} / \mathrm{ml}$; range, 0.3-9.5) was lower than the cut-off value; whereas, in the specimens from cancer patients, the mean value $(25 \pm 2.9 \mathrm{ng} / \mathrm{ml}$; range, 0.8-93) was higher than the cut-off value. However, when we considered the different origin of neoplasias we observed that in the breast carcinomas, HER-2/neu ranged from 10 to $93 \mathrm{ng} / \mathrm{ml}$ with a mean value $\pm \mathrm{SE}$ of $35.6 \pm 4.1 \mathrm{ng} / \mathrm{ml}$ (Table II); whereas, in the patients with lung, ovary or colon cancer the pleural fluid values of HER-2/neu (range, 0.8-14.2; mean, $7.5 \pm 1.1 \mathrm{ng} / \mathrm{ml}$ ) were included in the normal range

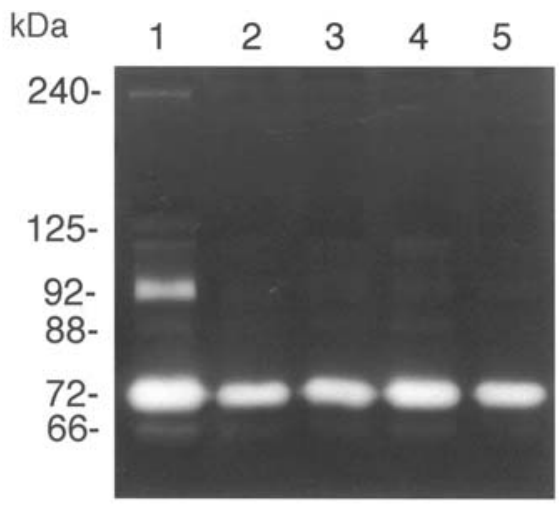

Figure 5. Gelatin zymography of pleural effusion specimens. Molecular weight standards are shown on the left. In all effusion samples, $15 \mu \mathrm{g}$ of protein was loaded onto the gel. Lanes 1-4, ovary cancer (patients GM, TA, PF, CA); lane 5 , colon cancer (patient TM).

(Table III). Finally, we observed that HER-2/neu was positive in $80 \%(16 / 20)$ of breast cancer samples and negative in all the specimens from all the other types of tumors analyzed. We found no association between gelatinolytic activities and high HER-2/neu ECD values.

\section{Discussion}

Despite the sophisticated diagnostic methods, definitive diagnosis of pleural effusions may still be difficult. In addition, the nature of pleural effusions is of particular importance in cancer patients and needs to be clarified, as a co-existing malignant pleural effusion implies an advanced stage (6). Thus, there is a great interest in identifying 'biomarkers' that can be used as an altenative method to enhance the sensitivity of cytological examination in the diagnosis of pleural effusions and/or add more information on the undiagnosed pleural effusions in order to select patients for thoracentesis.

Table III. Pleural effusion MMP content (volume $\mathrm{x} 10^{-3} / \mu \mathrm{g}$ protein and percentage) related to HER-2/neu in cancer.

\begin{tabular}{|c|c|c|c|c|c|c|c|c|c|c|c|c|c|}
\hline \multirow[b]{2}{*}{ Patient } & \multirow[b]{2}{*}{ Sex } & \multirow{2}{*}{$\begin{array}{c}\text { Age } \\
\text { (years) }\end{array}$} & \multirow{2}{*}{$\begin{array}{l}\text { Site of } \\
\text { tumor }\end{array}$} & \multirow{2}{*}{$\begin{array}{c}\text { Total MMPs } \\
\left.\text { (vol x } 10^{-3} / \mu \mathrm{g} \mathrm{pr}\right)\end{array}$} & \multicolumn{2}{|c|}{ MMP 92 kDa } & \multicolumn{2}{|c|}{ MMP 88 kDa } & \multicolumn{2}{|c|}{ MMP $72 \mathrm{kDa}$} & \multicolumn{2}{|c|}{ MMP 66 kDa } & \multirow{2}{*}{$\begin{array}{c}\text { HER-2/neu } \\
\text { (ng/ml) }\end{array}$} \\
\hline & & & & & A & B & A & B & A & B & A & B & \\
\hline AA & M & 53 & Lung & 18.8 & 0 & 0 & 0 & 0 & 18.8 & 100.0 & 0 & 0 & 12.7 \\
\hline PG & M & 70 & Lung & 32.8 & 17.5 & 53.0 & 0 & 0 & 15.3 & 46.6 & 0 & 0 & 3.2 \\
\hline $\mathrm{AP}$ & M & 78 & Lung & 70.5 & 1.0 & 1.4 & 0 & 0 & 69.5 & 98.6 & 0 & 0 & 0.8 \\
\hline $\mathrm{CG}$ & $\mathrm{F}$ & 52 & Lung & 29.7 & 0 & 0 & 0 & 0 & 29.7 & 100.0 & 0 & 0 & 6.2 \\
\hline DF & M & 70 & Lung & 35.6 & 1.8 & 5.0 & 0 & 0 & 33.7 & 95.0 & 0 & 0 & 14.2 \\
\hline DS & M & 63 & Lung & 44.8 & 0 & 0 & 0 & 0 & 39.5 & 88.0 & 5.2 & 12.0 & 3.1 \\
\hline GM & $\mathrm{F}$ & 61 & Ovary & 61.0 & 15.0 & 24.5 & 0 & 0 & 43.0 & 70.5 & 1.5 & 2.4 & 4.0 \\
\hline TA & $\mathrm{F}$ & 69 & Ovary & 23.5 & 0 & 0 & 0 & 0 & 23.5 & 100.0 & 0 & 0 & 9.8 \\
\hline $\mathrm{PF}$ & $\mathrm{F}$ & 74 & Ovary & 28.5 & 0 & 0 & 0 & 0 & 28.5 & 100.0 & 0 & 0 & 8.0 \\
\hline $\mathrm{CA}$ & $\mathrm{F}$ & 72 & Ovary & 39.5 & 0 & 0 & 0 & 0 & 39.5 & 100.0 & 0 & 0 & 8.7 \\
\hline $\mathrm{TM}$ & M & 70 & Colon & 27.6 & 0 & 0 & 0 & 0 & 27.6 & 100.0 & 0 & 0 & 10.5 \\
\hline MA & $\mathrm{F}$ & 50 & Colon & 26.0 & 1.2 & 4.6 & 0 & 0 & 24.8 & 95.4 & 0 & 0 & 9.0 \\
\hline
\end{tabular}

A, volume $\times 10^{-3} / \mu \mathrm{g}$ protein; B, percentage. pr, protein. 
Tumor progression is a multistep process. MMPs can promote cancer progression by increasing cancer-cell growth, migration, invasion metastasis and angiogenesis. MMPs exert these effects by cleaving a diverse group of substrates, which includes not only structural components of the extracellular matrix, but also growth-factor-binding proteins, growth-factor precursors, receptor tyrosine kinases, cell-adhesion molecules and other proteinases $(14,16)$. A member of the epidermalgrowth-factor receptor (EGF-R) family, HER-2/neu (also known as erb-B2), is substrate for MMPs. In this case, the extracellular domain of the receptor is released, and this might function as a decoy receptor for the ligand. Moreover, the expression of MMPs is regulated by a c-oncogene such as c-erb B2 $(20,21,28,29)$.

In the present report, we measured in the pleural effusions, in which diagnosis has already been made, the gelatinolytic levels of MMP-2 and MMP-9 by zymography and related the data with the soluble extracellular domain of HER-2/neu. Zymography has some advantages over immunological assay, such as lower cost, a more rapid time of execution and the possibility of simultaneously detecting multiple forms of the same enzyme. Our results demonstrated that substantial amounts of MMP-2 and, to a lesser degree MMP-9 are present in pleural effusions. MMP-2 lytic activity was present in all specimens analyzed and the values were 2.5 -fold higher in benign effusions than in malignant effusions. MMP-9 was detected in $59 \%$ of cancer patients and it was undetectable in cirrhosis specimens. Moreover, MMP-9 lytic activity was 8fold higher in pleurisy than in malignancy.

The gene product of the HER-2/neu functions as a normal epithelial protein in cell growth and proliferation. HER-2/neu gene amplification and protein overexpression contribute to converting healthy cells to cancer cells; however, the exact timing of HER-2/neu involvement in neoplastic transformation has not been determined. Nowadays, the HER-2/neu oncoprotein is recognized as an important factor in cancer development and has become established as an important diagnostic tool in the investigation of patients with cancer. The soluble extracellular domain (ECD) of HER-2/neu, cleaved by a mechanism involving MMP activity, is shed in human fluids and serum and it is measurable by immunoassay. HER-2/neu ECD has been proposed as a tool for assessing prognosis and early dectection of cancer progression in sera of breast cancer patients (30) and in pleural effusions from patients with lung carcinoma (31). The data shown here indicate that HER-2/ neu ECD is positive in $80 \%$ of breast cancer samples and negative in all the specimens from all the other types of tumor analyzed as well as in the benign pleural effusions. Although, we found no correlation between gelatinolytic activity and HER-2/neu ECD value in pleural effusions, our data suggest that the determination of these parameters might help to differentiate between malignant and benign effusions. To our best knowledge, others showed enhanced MMP-9 lytic activity in parainflammatory effusions and the MMP-9 value correlated with those of the $\mathrm{C}$ reactive protein, a systemic marker of inflammation (32). Furthermore, Davidson and colleagues reported increased levels of MMP-2 in cells by effusion from patients with ovarian and breast carcinoma and linked this factor to poor prognosis $(33,34)$. In regard to HER-2/neu ECD, there are different and contrasting reports in the literature.
Hung et al proposed HER-2/neu ECD as a potential tumor marker for a diagnosis of pleural effusions on patients with lung adenocarcinoma (31), whereas Porcel and colleagues reported that HER-2/neu ECD has poor diagnostic performance in patients with malignant effusions (35). We found that HER-2/neu ECD in pleural effusion might help to identify breast cancer and that the determination of MMPs might be useful to identify inflammatory diseases. Nevertheless, there are some limitations of our study: i) due to the small number of patients included in this observational study, the conclusion of our study may not be transferable to the general population and therefore need further evaluation; ii) we performed our experiments on pleural fluid supernatants and we were not able to establish the cellular source of the proteins analyzed. In fact, it is well known that in malignant effusions three cell populations (malignant cells, reactive mesothelial cells, inflammatory cells) are typically found. Therefore the relative contribution of each of these cellular components to the effusion cell population may vary considerably in different specimens. In our future research, the next step will be the analysis of the cellular content of MMP-2 and -9 in the cells of pleural effusions after the identification of each cell type.

\section{References}

1. Banerjee AK, Willetts I, Robertson JF and Blamey RW: Pleural effusion in breast cancer: a review of the Nottingham experience. Eur J Surg Oncol 20: 33-36, 1994.

2. Dieterich M, Goodman SN, Rojas-Corona RR, Emralino AB, Jimenez-Joseph D and Sherman ME: Multivariate analysis of prognostic features in malignant pleural effusions from breast cancer patients. Acta Cytol 38: 945-952, 1994.

3. Fenton KN and Richardson JD: Diagnosis and management of malignant pleural effusions: Am J Surg 170: 69-74, 1995.

4. Bedrossian CW: Diagnostic problems in serous effusions. Diagn Cytopathol 19: 131-137, 1998.

5. Porcel JM and Light RW: Diagnostic approach to pleural effusion in adults. Am Fam Physician 73: 1211-1229, 2006.

6. Neragi-Miandoab S: Malignant pleural effusion, current and evolving approaches for its diagnosis and management. Lung Cancer 54: 1-9, 2006.

7. Terracciano D, Di Carlo A, Papa P, Cicalese M, Maietta P, Cecere C, Mariano A and Macchia V: New approaches in the diagnostic procedure of malignant pleural effusion. Oncol Rep 12: 79-83, 2004

8. Porcel JM, Vives M, Esquerda A, Salud A, Perez B and Rodriguez-Panadero F: Use of a panel of tumor markers (carcinoembryonic antigen, cancer antigen 125, carbohydrate antigen 15-3, and cytokeratin 19 fragments) in pleural fluid for the differential diagnosis of benign and malignant effusions. Chest 126: 1757-1763, 2004.

9. Light RW: Tumor markers in undiagnosed pleural effusions. Chest 126: 1721-1722, 2004.

10. Shitrit D, Zingerman B, Bar-Gil Shitrit A, Shlomi D and Kramer MR: Diagnostic value of Cyfra 21-1, CEA, CA19-9, CA 15-3 and CA125 assays in pleural effusions: analysis of 116 cases and review of the literature. Oncologist 10: 501-507, 2005.

11. Ghayumi SMA, Mehrabi S, Doroudchi M and Ghaderi A: Diagnostic value of tumor markers for differentiating malignant and benign pleural effusions of Iranian patients. Pathol Oncol Res 11: 236-241, 2005.

12. Aaronson SA: Growth factor and cancer. Science 254: 1146-1153, 1991.

13. Hynes NE and Stern DF: The biology of erbB-2/neu/HER-2 and its role in cancer. Biochim Biophys Acta 1198: 165-184, 1994.

14. Egeblad $\mathrm{M}$ and Werb Z: New functions for the matrix metalloproteinases in cancer progression. Nat Rev Cancer 2: 161-174, 2002.

15. Di Carlo A, Terracciano D, Mariano A and Macchia V: Matrix metalloproteinase-2 and matrix metalloproteinase-9 type IV collagenase in serum of patients with pleural effusions. Int $\mathbf{J}$ Oncol 26: 1363-1368, 2005. 
16. Björklund $\mathrm{M}$ and Koivunen E: Gelatinase-mediated migration and invasion of cancer cells. Biochim Biophys Acta 1755:37-69, 2005.

17. Giunciuglio D, Culty M, Fassina G, Masiello L, Melchiori A, Paglialunga G, Arand G, Ciardiello F, Basolo F, Thompson EW and Albini A: Invasive phenotype of MCF10A cells overexpressing c-Ha-ras and c-erbB-2 oncogenes. Int J Cancer 63: 815-822, 1995.

18. Kaya M, Yoshida K, Higashino F, Mitaka T, Ishii S and Fujinaga K: A single ets-related transcription factor, E1AF, confers invasive phenotype on human cancer cells. Oncogene 12: 221-227, 1996.

19. Leitzel K, Teramoto Y, Sampson E, Mauceri J, Langton BC, Demeres L, Podczaski E, Harvey H, Shambaugh S and Volas G: Elevated soluble c-erbB-2 antigen levels in the serum effusions of a preparation of breast cancer patients. J Clin Oncol 10: 436-443, 1992.

20. Pupa SM, Menard S, Morelli D, Pozzi B, De Palo G and Colnaghi MI: The extracellular domain of the c-erbB-2 oncoprotein is released from tumor cells by proteolytic cleavage. Oncogene 8: 2917-2923, 1993.

21. Codony-Servat J, Albanell J, Lopez-Talavera JC, Arribas J and Baselga J: Cleavage of the HER-2 ectodomain is a pervanadateactivable process that is inhibited by the tissue inhibitor of matrixmetalloproteinase-1 in breast cancer cells. Cancer Res 59: 1196-1201, 1999

22. Bradford MM: A rapid and sensitive method for quantitation of microgram quantities of protein utilizing the principle of proteindye binding. Anal Biochem 72: 248-254, 1976.

23. Di Carlo A, Terracciano D, Mariano A and Macchia V: Urinary gelatinase activities (matrix metalloproteinases 2 and 9) in human bladder tumors. Oncol Rep 15: 1321-1326, 2006.

24. Light RW: Clinical practice. Pleural effusion. N Engl J Med 346: 1971-1977, 2002.

25. Triebel S, Blaser J, Reinke H and Tschesche H: A $25 \mathrm{kDa}$ alpha 2 -microglobulin-related protein is a component of the $125 \mathrm{kDa}$ form of human gelatinase. FEBS Lett 314: 386-388, 1992.

26. Yan L, Borregaard N, Kjeldsen L and Moses MA: The high molecular weight urinary matrix metalloproteinase (MMP) activity is a complex of gelatinase B/MMP and neutrophil gelatinase-associated lipocalin (NGAL). J Biol Chem 276: 37258-37265, 2001.
27. Goldberg GI, Strongin A, Collier IE, Genrich LT and Marmer BL: Interaction of 92-kDa type IV collagenase with the tissue inhibitor of metalloproteinases prevents dimerization, complex formation with interstitial collagenase, and activation of proenzyme with stromelysin. J Biol Chem 267: 4583-4591, 1992.

28. Rundhaug JE: The biology behind matrix metalloproteinases, angiogenesis and cancer. Clin Cancer Res 9: 551-554, 2003.

29. Molina MA, Codony-Servat J, Albanell J, Rojo F, Arribas J and Baselga J: Trastuzumb (Herceptin), a humanized anti-HER-2/ neu receptor monoclonal antibody inhibits basal and activated HER2 ectodomain cleavage in breast cancer cells. Cancer Res 61: 4744-4749, 2001

30. Carney WP, Neumann R, Lipton A, Leitzel K, Ali S and Price CP: Potential clinical utility of serum HER-2/neu oncoprotein concentrations in patients with breast cancer. Clin Chem 49: 1579-1598, 2003.

31. Hung TL, Chen FF, Liu JM, Lai WW, Hsiao AL, Huang WT, Chen HHW and Su WC: Clinical evaluation of HER-2/neu protein in malignant pleural effusion-associated lung adenocarcinoma and as a tumor marker in pleural effusion diagnosis. Clin Cancer Res 9: 2605-2612, 2003.

32. Kotyza J, Pesek M, Bednárova V, Terl M and Werle B: Pleural fluids associated with metastatic lung tumors are rich in progelatinase B/proMMP-9. Neoplasma 52: 388-392, 2005.

33. Davidson B, Reich R, Berner A, Givant-Horwitz V, Goldberg I, Risberg B, Kristensen GB, Trope CG, Bryne M, Kopolovic J and Nesland JM: Ovarian carcinoma cells in serous effusions show altered MMP-2 and TIMP-2 mRNA levels. Eur J Cancer 37: 2040-2049, 2001.

34. Davidson B, Konstantinovsky S, Nielsen S, Dong HP, Berner A, Vyberg $M$ and Reich R: Altered expression of metastasisassociated and regulatory molecules in effusions from breast cancer patients: a novel model for tumor progression. Clin Cancer Res 10: 7335-7346, 2004

35. Porcel JM, Salud A, Vives M, Esquerda A and RodriguezPanadero F: Soluble oncoprotein $185^{\mathrm{HER}-2}$ in pleural fluid has limited usefulness for the diagnostic evaluation of malignant effusions. Clin Biochem 38: 1031-1033, 2005. 